\title{
THE IMPORTANCE OF THE OCCUPATIONAL VOCAL LOAD FOR THE OCCURENCE AND TREATMENT OF ORGANIC VOICE DISORDERS
}

\section{VPLIV GLASOVNE OBREMENITVE PRI POKLICU NA POJAV IN ZDRAVLJENJE ORGANSKO POGOJENIH GLASOVNIH TEŽAV}

\author{
Miha ZABRET ${ }^{1 *}$, Irena HOČEVAR BOLTEŽAR ${ }^{1}$, Maja ŠEREG BAHAR ${ }^{1}$
}

\begin{abstract}
${ }^{1}$ University Clinical Center Ljubljana, Department for Otorhinolaryngology and Cervicofacial Surgery, Zaloska cesta 2, 1000 Ljubljana, Slovenia
\end{abstract}

\section{ABSTRACT \\ Keywords: \\ hoarseness, workload, occupations, therapy, health services accessibility, occupational health workplace}

\section{IZVLEČEK}

Ključne besede: delovna obremenitev, zaposlitev, zdravljenje, dostopnost do zdravstvenih storitev, zdravje na delovnem mestu, delovno mesto
Introduction: The voice represents a basic working tool for carrying out certain occupations. Hoarseness, as a consequence of vocal fold lesions, presents an important cause of work-related absences for voice professionals.

Methods: Our study was designed as a retrospective cohort one. Data on gender, workplace, vocal load and exposure to risk factors for voice disorders of the patients who had surgery in the 2014-2015 period at the tertiary centre due to benign vocal fold lesions were collected from their clinical records. We compared professional voice users (PVU) to subjects with no vocal load at work (NPVU). The SPSS programme, version 22.0, was used for statistical analysis.

Results: From 2014 to 2015, 103 PVU and 132 NPVU were surgically treated for benign vocal fold lesions. In comparison to the second group, loud speech use was reported significantly more often by PVU $(40.8 \%$ vs. $14.4 \%)$, as was a fast speaking rate $(22.3 \%$ vs. $9.8 \%)$ and additional vocal load outside of the workplace $(23.3 \%$ vs. $12.9 \%$ ). The time that had passed between the occurrence of the hoarseness and the surgical treatment did not differ between the groups. The majority of patients were satisfied with the outcome of the operation.

Conclusions: Nearly a half of the operated patients had a considerable vocal load at work. An ENT assessment prior to starting a job as well as priority phoniatric treatment of voice disorders for PVU would significantly reduce the costs of work absences and contribute to a speedier recovery and return to the workplace.

Uvod: Glas je osnovno delovno orodje pri opravljanju nekaterih poklicev. Hripavost, ki nastane kot posledica lezij glasilk, je pri osebah, ki opravljajo delo z glasovno obremenitvijo, vzrok za bolniško odsotnost z dela, kar pomeni tudi večje ekonomsko breme za državo.

Metode: Raziskavo smo zasnovali kot retrospektivno kohortno. Podatke o spolu, delovnem mestu, glasovni obremenitvi in izpostavljenosti dejavnikom tveganja za razvoj benignih lezij glasilk za bolnike, ki so bili v letih 2014 in 2015 operirani na Kliniki za otorinolaringologijo in cervikofacialno kirurgijo v Ljubljani zaradi benignih zamejenih sprememb na glasilkah, smo povzeli iz njihove zdravstvene dokumentacije. Primerjali smo osebe s poklicno glasovno obremenitvijo pri delu in tiste brez nje. Podatke smo statistično analizirali s programom SPSS, različico 22.0.

Rezultati: V letih 2014 in 2015 je bilo operiranih 235 bolnikov z benignimi lezijami glasilk. Med njimi so bili 103 glasovni profesionalci, preostalih 132 oseb pa je bilo brez glasovne obremenitve pri delu. V 90,6\% primerov se je motnja kazala s hripavostjo. Bolniki obeh skupin so bili najpogosteje operirani zaradi polipa ali Reinkejevega edema. Glasovni profesionalci so pomembno pogosteje navajali glasen govor (40,8 \% proti 14,4 $\%$ ), hiter govorni tempo (22,3\% proti $9,8 \%$ ) in dodatno glasovno obremenitev poleg službe (23,3 \% proti 12,9 $\%)$ kakor osebe brez glasovnega napora pri delu. Čas od pojava hripavosti do kirurškega zdravljenja se med skupinama ni razlikoval. Pred operacijo je imelo logopedsko obravnavo 22,5\% bolnikov, pooperativno pa 36,6 $\%$. Tri tedne po posegu je $81,6 \%$ glasovnih profesionalcev in $85,6 \%$ oseb brez glasovne obremenitve pri delu izrazilo zadovoljstvo z izidom operacije.

Zaključki: Skoraj polovica oseb, ki so operirane zaradi benignih lezij na glasilkah, je pri svojem delu glasovno obremenjenih. Hripavost jih pomembno ovira pri opravljanju njihovega poklica. Otorinolaringološka ocena zmožnosti opravljanja poklica z glasovno obremenitvijo in prednostna foniatrična obravnava glasovnih motenj glasovnih profesionalcev bi pomembno znižali stroške bolniške odsotnosti z dela in pripomogli k hitrejši vrnitvi na delovno mesto. 


\section{INTRODUCTION}

A good voice is a crucial component of human communication and thus an essential working tool for certain occupations with a vocal load (1). In modern societies, about one-third of the labour force works in occupations for which the voice is the primary tool (2). There are several classifications of professions according to occupational vocal demands. Koufman and Isaacson defined four levels of vocal users. The first level includes elite vocal performers (singers, actors), the second level encompasses professional voice users (clergy, lecturers, telephone operators), the third level is made up of nonvocal professionals (other teachers, doctors, lawyers) and the fourth level consists of non-vocal non-professionals (labourers, clerks) (3).

The most important cause for vocal fold damage is longlasting voice abuse or overuse, which is frequently detected in occupations with a high vocal load (3). Consequently, benign vocal fold lesions tend to develop. Among them, vocal nodules, polyps, Reinke's oedema, cysts and granulomas are the most common (4). The treatment of these benign vocal fold lesions should be causally orientated. In the majority of cases, the microsurgical removal of the epithelial lesion from the voice generator (vocal folds) is performed (5). Proper vocal habits and voice therapy prior to and following surgical treatment are necessary in order to correct phonation techniques and to prevent a recurrence (6).

Vocal fold lesions cause voice impairment. In the case of voice professionals with a great voice load at work and/or a demand for high voice quality, the voice disorder can be the reason for the inability to perform his/her occupation (7). Therefore, vocal fold lesions in voice professionals present an inevitable cost caused by long-lasting sick leave.

In terms of the general population, the estimated lifetime prevalence of voice disorders is $29.9 \%$ with a $6.6 \%$ possibility of having a current voice disorder (8). The USA recorded $2.1 \%$ days of work missed due to laryngeal disorders, and an average annual income loss of $\$ 843.198 .30$ in the period from 2004 to 2008 (9). It can be assumed that the majority of the working force on sick leave due to voice problems is exclusively vocal professionals (Levels I-III, according to Koufman and Isaacson) (3).

A meta-analysis of 6 papers on voice disorders in occupations with vocal load showed that more than $82 \%$ of the 2347 included subjects had voice problems at some time during their career. The prevalent causes of voice problems included the vocal load or respiratory tract infections. Teachers were most often affected by voice problems (10). There are also other studies reporting on high risk of voice disorders among teachers $(11,12)$. As a matter of fact, professional voice users represent a vast majority of therapy-seeking population with voice disorders (12).

The aim of the present study was to determine the proportion of vocal professionals among the subjects who underwent the phonomicrosurgical procedure for benign vocal fold lesions in the period from 2014 to 2015, at the University Department of Otorhinolaryngology and Cervicofacial Surgery (Univ. Dept. of ORL) in Ljubljana, as well as to state the possible influence of the vocal load at work on the success of the treatment.

\section{METHODS}

The study was a retrospective cohort one. The medical documentation of all patients who were surgically treated for benign vocal fold lesions in the Centre for Voice, Speech and Swallowing Disorders, at the Univ. Dept. of ORL in Ljubljana, in the period from 2014 to 2015, was reviewed. According to the study protocol, the following data was obtained from the documentation: age, gender, the patients' voice problems and their duration before surgery ( $<1$ year, $>1$ year), the level of the patients' occupational vocal load, classifying them into one of the four levels of voice users (3), vocal habits (excessive loud speech, fast speech rate), exposure to background noise and an unfavourable microclimate at their workplace, smoking status (non-smoker, smoker), possible allergies to inhalatory and nutritive allergens, hearing impairment, vocal load outside of the workplace (e.g. singing in a choir, being a coach for different team sports), irritating cough, symptoms of gastroesophageal reflux, histological diagnosis of the surgically removed vocal fold lesion, participation in voice therapy before and after surgery, possible residual hoarseness and voice quality satisfaction 3 weeks after the treatment.

According to the vocal load that was reported by the patients, they were classified into Levels I-IV according to Koufman and Issacson (3). The patients with vocal load at work (Levels I-III, professional voice users - PVU) were compared to the patients without vocal load at work (Level IV, nonprofessional voice users - NPVU) with regards to voice complaints before the surgical procedure, different risk factors for the occurrence of vocal fold lesions, persistent hoarseness and voice quality satisfaction following the surgical procedure as well as voice therapy attendance both before and after the operation. 
The SPSS 22.0 (SPSS Corporation, USA) programme package was used for the statistical analysis. Besides descriptive statistics, the following tests were used: the $\chi^{2}$-test or Fischer's exact test, the t-test and the nonparametric Mann Whitney test (in the case of a nonnormal arrangement of the data). The significance level was set at 0.05 .

The study was performed in accordance with the ethical standards laid down in the Declaration of Helsinki. It was retrospective and part of the regular assessment of the success of treatment at the Univ. Dept. of ORL. Therefore, no additional ethical approval was required.

\section{RESULTS}

In the period from 2014 to 2015, 235 patients ( 99 men, 136 women) with benign organic lesions of the vocal folds were surgically treated. The average age of patients at the time of surgery was $44.84 \pm 14.38$ years (range 6-85 years).

Among surgically treated patients, there were $6(2.5 \%)$ elite vocal performers (Level I), 32 (13.6\%) professional voice users (Level II), 65 (27.7\%) non-vocal professionals (Level III) and 132 (56.1\%) non-vocal non-professionals (Level IV). Thus, 103 patients reported vocal load at work (PVU, Levels I-III). 36 subjects declared working in the field of education (28 subjects from Level II, 8 subjects from Level III). Among them were 31 women who presented a significant difference in comparison with the subjects not working in education (women 104/198; $p=0.01$ ).
Before the surgical procedure, hoarseness was reported by $213(90.6 \%)$ individuals, lower pitch by 22 patients $(9.4 \%)$ and voice fatigue by $11(4.7 \%)$ patients. Before the surgical procedure, 105 patients reported different voice problems lasting up to one year and 117 patients had voice problems for more than one year leading up to the operation. Data was missing for 13 patients.

After the surgical procedure, 25 (10.6\%) patients reported persistent hoarseness and $27(11.5 \%)$ patients had voice problems after the vocal load. 12 (5.1\%) patients reported a normal voice and having minor problems, only during respiratory tract infections. All other subjects did not have any residual voice problems.

In the PVU group, there were 33 men and 70 women. In the NPVU group, there were 66 men and 66 women. The gender difference was significant $(p=0.008)$. The mean age of the NPVU patients was significantly higher $47.56 \pm 15.79$ years $)$ than in the PVU group $(41.35 \pm 11.51$ years) $(\mathrm{p}=0.01)$.

Before surgery, the PVU patients more often had a lower voice pitch than the NPVU group (Table 1). The comparison of the groups showed no significant difference regarding the type of vocal fold lesion (Table 2). The PVU patients more frequently used excessive loudness in speech and a fast speech rate and had a more frequent vocal load outside work than the NPVU patients (Table 3). The PVU group more frequently reported persistent hoarseness or voice problems after the postoperative vocal load than the NPVU group (Table 4).

Table 1. The comparison of the type and duration of voice problems before the surgical procedure in patients with vocal fold lesions with regard to their vocal load at work.

\begin{tabular}{|c|c|c|c|c|c|}
\hline \multirow[b]{2}{*}{ Symptom } & \multicolumn{2}{|c|}{ PVU $(\mathrm{N}=103)$} & \multicolumn{2}{|c|}{ NPVU $(N=132)$} & \multirow[b]{2}{*}{$\mathrm{p}$} \\
\hline & $\begin{array}{l}\text { Number of } \\
\text { cases }\end{array}$ & $\begin{array}{c}\text { Percentage } \\
\text { (\%) }\end{array}$ & $\begin{array}{l}\text { Number of } \\
\text { cases }\end{array}$ & $\begin{array}{c}\text { Percentage } \\
\text { (\%) }\end{array}$ & \\
\hline Hoarseness & 91 & 88.3 & 122 & 92.2 & 1.000 \\
\hline Lower pitch & 15 & 14.6 & 7 & 5.3 & 0.023 \\
\hline Voice fatigue & 7 & 6.8 & 4 & 3.0 & 0.219 \\
\hline \multicolumn{6}{|c|}{ Duration of voice problems $(\mathrm{N}=222)$} \\
\hline$\leq 1$ year & 49 & 47.6 & 56 & 42.4 & 0.419 \\
\hline$>1$ year & 48 & 46.6 & 69 & 52.3 & \\
\hline Missing data & 6 & 5.8 & 7 & 5.3 & \\
\hline
\end{tabular}

PVU=professional voice users, Levels I-III; NPVU=non-professional voice users, Level IV 
Table 2. The comparison of the type of lesion in patients with vocal fold lesionswith regard to their vocal load at work.

\begin{tabular}{|c|c|c|c|c|c|}
\hline \multirow[b]{2}{*}{ Lesion type } & \multicolumn{2}{|c|}{ PVU $(\mathrm{N}=103)$} & \multicolumn{2}{|c|}{ NPVU $(N=132)$} & \multirow[b]{2}{*}{$\mathrm{p}$} \\
\hline & $\begin{array}{l}\text { Number of } \\
\text { cases }\end{array}$ & $\begin{array}{c}\text { Percentage } \\
\text { (\%) }\end{array}$ & $\begin{array}{l}\text { Number of } \\
\text { cases }\end{array}$ & $\begin{array}{c}\text { Percentage } \\
\text { (\%) }\end{array}$ & \\
\hline Polyp & 38 & 36.9 & 61 & 46.2 & 0.193 \\
\hline Reinke's edema & 33 & 32.0 & 38 & 28.8 & 0.590 \\
\hline Laryngeal papillomatosis & 12 & 11.7 & 7 & 5.3 & 0.076 \\
\hline Vocal nodules & 9 & 8.7 & 9 & 6.8 & 0.780 \\
\hline Cyst & 5 & 4.9 & 10 & 7.6 & 0.390 \\
\hline Chronic laryngitis & 4 & 3.9 & 5 & 3.8 & 0.970 \\
\hline Granuloma & 2 & 1.9 & 2 & 1.5 & 0.800 \\
\hline
\end{tabular}

PVU=professional voice users, Levels I-III; NPVU=non-professional voice users, Level IV

Table 3. The comparison of the risk factors for vocal fold lesion occurrence in patients with regard to their vocal load at work.

\begin{tabular}{|c|c|c|c|c|c|}
\hline \multirow[b]{2}{*}{$\begin{array}{l}\text { Risk factors for vocal fold } \\
\text { lesion development }\end{array}$} & \multicolumn{2}{|c|}{ PVU $(N=103)$} & \multicolumn{2}{|c|}{ NPVU $(N=132)$} & \multirow[b]{2}{*}{$\mathrm{p}$} \\
\hline & $\begin{array}{l}\text { Number of } \\
\text { cases }\end{array}$ & $\begin{array}{c}\text { Percentage } \\
\text { (\%) }\end{array}$ & $\begin{array}{l}\text { Number of } \\
\text { cases }\end{array}$ & $\begin{array}{c}\text { Percentage } \\
\text { (\%) }\end{array}$ & \\
\hline Loud speech & 42 & 40.8 & 19 & 14.4 & $<0.001$ \\
\hline Fast speaking rate & 23 & 22.3 & 13 & 9.8 & 0.010 \\
\hline Vocal load outside work & 24 & 23.3 & 17 & 12.9 & 0.037 \\
\hline Background noise & 33 & 32.0 & 40 & 30.3 & 0.773 \\
\hline Unfavorable microclimate & 11 & 10.7 & 23 & 17.4 & 0.191 \\
\hline Smoking & 48 & 46.7 & 74 & 56.1 & 0.190 \\
\hline Symptoms of GER & 28 & 27.2 & 41 & 31.1 & 0.565 \\
\hline Allergy & 31 & 30.1 & 34 & 25.8 & 0.467 \\
\hline Irritating cough & 11 & 10.7 & 11 & 8.3 & 0.653 \\
\hline Hearing impairment & 1 & 1 & 3 & 2.3 & 0.633 \\
\hline
\end{tabular}

PVU=professional voice users, Levels I-III; NPVU=non-professional voice users, Level IV; GER=gastroesophageal reflux

Table 4. The comparison of voice problems following the surgical procedure in patients with vocal fold lesions with regard to their vocal load at work.

\begin{tabular}{|c|c|c|c|c|c|}
\hline \multirow[b]{2}{*}{ Hoarseness after surgery } & \multicolumn{2}{|c|}{ PVU $(\mathrm{N}=103)$} & \multicolumn{2}{|c|}{ NPVU $(N=132)$} & \multirow[b]{2}{*}{$\mathrm{p}$} \\
\hline & $\begin{array}{c}\text { Number of } \\
\text { cases }\end{array}$ & $\begin{array}{l}\text { Percentage } \\
\text { (\%) }\end{array}$ & $\begin{array}{l}\text { Number of } \\
\text { cases }\end{array}$ & $\begin{array}{c}\text { Percentage } \\
\text { (\%) }\end{array}$ & \\
\hline No or only after URI & 73 & 70.9 & 110 & 83.3 & 0.039 \\
\hline Yes, persistent or after voice effort & 30 & 29.1 & 22 & 16.7 & \\
\hline
\end{tabular}

PVU=professional voice users, Levels I-III; NPVU=non-professional voice users, Level IV; URI= upper respiratory tract infection 
$53(22.5 \%)$ patients attended preoperative voice therapy and 86 patients ( $36.6 \%$ ) did so postoperatively. There were no significant differences in voice therapy attendance between the two groups (Table 5). Among the 86 patients who attended voice therapy following the surgery, there were 37 patients who already had voice therapy before the surgical procedure.

There were 44 (42.7\%) PVU and 58 (43.9\%) NPVU patients who attended voice therapy before and/or after the surgical procedure.

Table 5. The comparison of voice therapy before and after the surgical procedure in patients with vocal fold lesions with regard to their vocal load at work.

\begin{tabular}{|c|c|c|c|c|c|}
\hline \multirow[b]{2}{*}{ Voice therapy } & \multicolumn{2}{|c|}{ PVU $(\mathrm{N}=103)$} & \multicolumn{2}{|c|}{ NPVU $(N=132)$} & \multirow[b]{2}{*}{$\mathrm{p}$} \\
\hline & $\begin{array}{l}\text { Number of } \\
\text { cases }\end{array}$ & $\begin{array}{c}\text { Percentage } \\
\text { (\%) }\end{array}$ & $\begin{array}{l}\text { Number of } \\
\text { cases }\end{array}$ & $\begin{array}{c}\text { Percentage } \\
\text { (\%) }\end{array}$ & \\
\hline Before surgery & 20 & 19.4 & 33 & 25.0 & 0.345 \\
\hline After surgery & 39 & 37.9 & 47 & 35.6 & 0.891 \\
\hline Before and/or after surgery & 44 & 42.7 & 58 & 43.9 & 0.792 \\
\hline
\end{tabular}

PVU=professional voice users, Levels I-III; NPVU=non-professional voice users, Level IV

Among the patients who had permanent postoperative voice problems or after the vocal load, a half of them $(26$ subjects) subsequently joined voice therapy. Only onethird of the subjects $(60 / 181)$ without voice problems continued voice therapy after the procedure $(p=0.034)$.

Among the patients who attended voice therapy before the surgical procedure, only $15.1 \%(8 / 53)$ had voice problems after the surgery, while among the patients who went without voice therapy before the surgery, there were $24.4 \%(44 / 180)$ with residual postoperative hoarseness $(p=0.190)$.

In the first postoperative assessment, 3 weeks after the surgery, 84 (81.6\%) PVU patients and 113 (85.6\%) patients from the NPVU group expressed satisfaction with their voice. There was no significant difference detected between the two groups $(p=0.278)$.

Among the patients who were not satisfied with the quality of their voice, there were 31 patients with persistent voice problems and only 5 patients without voice problems $(p<0.001)$.

\section{DISCUSSION}

In the period from 2014 to 2015, 103 individuals who directly depended on their voice in their profession (PVU) and 132 individuals who carried out their profession irrespective of their voice quality (NPVU) were surgically treated for benign vocal fold lesions at the Univ. Dept. of ORL. In the PVU group (Levels I-III according to Koufman and Isaacson (3)), there were significantly more women, more subjects declaring using excessive loudness and a fast speaking rate in their communication, and also more patients with an additional vocal load outside of work than in the NPVU group (Level IV). The workplace vocal load (Levels I-III) was a negative predictive factor for good voice quality after the surgical procedure. Only $22.6 \%$ of all patients had voice therapy before the surgical procedure, and only $36.6 \%$ of patients attended voice therapy after the surgery. In any case, 197 (83.4\%) patients expressed their satisfaction with their voice quality following the surgical procedure. Among those who were not satisfied with the quality of their voice, there were significantly more patients with persistent voice problems than patients without them.

For the purposes of our study, we formed two groups - PVU and NPVU. The subjects in the first group (PVU) depended on voice quality as a primary tool of their trade. In the other group (NPVU), the quality of their voice did not influence their occupational performance. In either the first or the second group, hoarseness was the leading symptom of a benign vocal fold lesion. The fact that hoarseness is the most common symptom of epithelial vocal fold lesions was also confirmed by other researchers (13). Hoarseness can lead to an occupational disability as some occupations directly depend on good voice quality. De Medeiros et al. from Brazil reported that $30 \%$ of female teachers miss work because of voice disorders at least once a year (14). In the USA, Roy et al. reported a 7.2\% absence from work regardless of profession. 1\% of USA employees are forced to change their working post due to voice disorders, and 
4.3\% of people indicated that their voice had limited or rendered them unable to do certain tasks in their current job (8). Three different studies reported that $13.6 \%$ of the working population missed work due to voice-related problems (15-17). Thus, voice problems are an important cause of sick leave in the population.

Ageneralised linear regression model in a survey performed by Cohen et al. revealed that a visit to an ENT specialist after a period of more than one month, following the first primary medical care visit, brings additional costs to the community. In other words, a visit to an ENT specialist with a time delay of 1-3 months and a delay of even more than 3 months means a cost increase of $\$ 271.34$ and $\$ 711.38$, respectively. They concluded that the immediate medical help of a proper specialist decreases the financial burden on the community (18).

According to our clinical practice and a meta-analysis of six papers on voice problems among voice users, a great majority of the patients with voice disorders are PVU and women (10). As the speech pathologist is a member of the team in the Centre for Voice, Speech and Swallowing Disorders, the majority of the patients with vocal fold nodules are successfully treated with voice therapy. This can be the reason why the majority of the surgically treated patients in the study were NPVU and why the patients with vocal fold nodules represented only $7.7 \%$ of all included patients.

Surprisingly, during our study, the time between the development of voice symptoms and surgery was about the same in both PVU and NPVU. We supposed that PVU, while depending on good voice quality in performing their work, would seek help earlier than NPVU. A possible reason for such a delay in seeking proper help even in PVU would be that 20 PVU attended voice therapy before the surgical procedure. The duration of the voice therapy presented a part of the delay before going to the operation. The reason for such a delay in the other PVU was not completely clear from the results of the study. One of the possible reasons could be limited access to the secondary and tertiary medical care in Slovenia, which also includes speech pathologists who specialise in voice disorders.

A significantly higher percentage of women was detected in the PVU group (68\%) when compared to NPVU group (50\%). In addition to a higher vocal load attributed to the nature of their occupation, the higher pitch of a female voice also presents a risk factor for the voice quality of this group. The female vocal fold oscillation frequency tends to be higher than in males; therefore, it indicates a greater chance of phonotrauma while practicing their occupation. Phonotrauma is the most important cause of benign epithelial lesions on vocal folds (19).
Another risk factor for the voice overuse and thus benign vocal fold lesions development that was detected in PVU group was an additional vocal load outside work. 35\% of PVU work in the field of education. We supposed that they also lecture and carry out tutorial activities outside of working hours. Exact information about the type of vocal load outside of the workplace was not found in the medical documentation. This may be a case where the load exceeds the speaker's vocal capacities, causing phonotrauma and leading to an epithelial lesion on the vocal folds. Other authors also report that high vocal load influences the frequency and severity of vocal tract problems (20).

There are a lot of other factors involved in maintaining proper voice quality, especially when the voice is an important working tool. The ergonomics, quality of the working environment and proper voice techniques are the most crucial factors. Unfortunately, the PVU are not always aware of the importance of their voice quality.

We determined that both groups were similarly exposed to different risk factors (background noise and unfavourable microclimates at their workplaces, smoking) and had similar health problems influencing voice quality (gastroesophageal reflux, hearing impairment, allergies, irritating cough). Nevertheless, we observed that the PVU from our study used excessive loudness in speech and a fast speaking rate more often than was reported by other researchers $(17,21)$. According to the results, we can say that $41 \%$ of our PVU abused their voices. Work-related voice overuse or abuse is an important cause for the occurrence of vocal fold lesions. The result of these lesions is hoarseness, which threatens the communicative, interactive and economic efficiency of the PVU. Therefore, a preventive programme with information about proper voice and speech techniques would be helpful in decreasing the morbidity of the PVU and, consequently, work absences (22-26).

Working-environmental ergonomics turned out to be comparable between PVU and NPVU. Both were similarly exposed to background noise and an unfavourable microclimate. Sala et al. related high background noise and poor acoustics in the rooms to the high prevalence of voice problems among teachers in Finland (27). Hence, higher standards of ergonomic conditions regarding voice and acoustics should be demanded for PVU than for NPVU. In our study, more than one-third of PVU were exposed to noise and/or irritating substances at their workplaces. The results of the study showed that approximately one half of the participants in both groups were smokers. The correlation between smoking and some vocal fold lesions' development is well-known (28-31). Our results show a similar distribution of smokers among PVU and NPVU. Despite the fact that the harmfulness of smoking 
in terms of one's voice quality is well established, almost one half of PVU smoked. We suppose that the inclusion of the data on vocal hygiene in the curriculum of the study programmes for professions with vocal load at work and/ or high voice quality demand would decrease the number of smokers among PVU.

A healthy vocal tract is a prerequisite for practicing an occupation with a vocal load. In Slovenia, no ENT examination is required before starting studies for occupations with vocal load, except for drama actors (1). At least a questionnaire about pre-existing voice problems would enable the identification of individuals without the sufficient physical capabilities for work with vocal load before starting their studies.

Further on, consistent voice training is necessary to maintain healthy vocal tract. In Slovenia, only students of drama acting, speech pathology and future priests receive lessons on vocal hygiene and voice technique (1). In order to decrease voice problems among PVU, it would be necessary to include proper information in the regular curriculum of their study programmes. After commencing work in an occupation with a considerable vocal load, regular periodic seminars on proper voice care should be organized for PVU.

Many developed countries have not yet labelled dysphonia as an occupational disease. Dysphonia related to a high vocal load during work is considered an occupational disease in France, Italy and Russia, but not yet in other European countries $(1,10)$. Of course, the prerequisite for the recognition of certain laryngeal diseases (e.g. vocal fold nodules, muscle tension dysphonia resistant to multidisciplinary treatment) for an occupational disease is a healthy vocal tract prior to practicing a certain occupation. The future PVU must prove to be fit for the vocal load before working in an occupation with a vocal load.

The majority of vocal professionals do not have immediate access to a professional ENT specialist's assessment and care when necessary. Cohen et al. showed that the treatment of voice disorders by general practitioners is comparable to the treatment by ENT specialists. This is not the case when surgical treatment is necessary and, hence, vocal professionals are often subject to a suboptimal choice of therapy and, thus, to a prolonged voice impairment hazard (32). Some studies suggest that many voice impairments remain misdiagnosed and many general practitioners' referrals are not eligible, thus extending waiting periods for adequate treatment $(8,33)$. Among patients with persistent voice problems, there were more PVU than NPVU. We can only speculate on the reason for such a distribution. It is possible that the PVU returned to their work with a vocal load before their vocal folds were completely healed. It is also possible that a considerable number of them did not possess proper vocal techniques due to the lack of proper voice education. Only less than one half of the PVU with a benign epithelial lesion caused by phonotrauma attended voice therapy before or/and after the operation. Thus, the fundamental problem for their voice impairment was not eliminated and caused persistent trouble after the successful removal of the lesion from the vocal fold. Unfortunately, the access to a suitable voice therapy is very limited in Slovenia.

The duration of procedures from the occurrence of the voice disorder to the appropriate multidisciplinary treatment in Slovenia is relatively long, but equally accessible for both groups: the PVU and NPVU. Both categories are considered fully equivalent, although the working efficiency of the first group directly depends on the quality of their voices, unlike the other group. In our opinion, a priority treatment of PVU with voice disorders by a specialised voice team would contribute to a faster return of a PVU to work and thus lower the sick leave costs for the community.

\section{CONCLUSION}

It was estimated that about one-third of the labour force works in occupations with vocal load. According to the results of our study, the PVU represent almost one half of the subjects surgically treated for benign vocal fold lesions. The PVU tend to be exposed to similar risk factors for the development of voice disorders as the NPVU. However, in comparison to the NPVU, loud speech use, a fast speaking rate and an additional vocal load outside of the workplace were reported significantly more often by the PVU. Further on, they have few opportunities for appropriate voice technique training and to learn about vocal hygiene. With the exception of future drama actors, there are no official demands for a healthy vocal tract before entering various study programmes for future PVU. More efficient preventive measures prior to committing to such studies and better educational possibilities in the regular curriculum would probably decrease the number of PVU who experience voice problems and miss work because of them. The future PVU should also receive the indubitable information that they are responsible for their own health and should do their best to care for it. Nevertheless, when PVU develop serious voice problems during their careers, a priority access to the proper health care should be provided.

The possibility of putting certain laryngeal diseases on the list of occupational diseases should be reconsidered in Slovenia. However, before including certain laryngeal diseases in such a list, multiple predetermined agreements will be necessary, such as a vocal tract capabilities screening method for candidates for occupations with 
vocal load, an otorhinolaryngological examination before starting working in an occupation with vocal load, a precise determination of vocal load at workplace and a demand for responsible voice usage.

\section{CONFLICTS OF INTEREST}

The authors declare no conflicts of interest exist.

\section{FUNDING}

The study was not financed.

\section{ETHICAL APPROVAL}

As the study was retrospective, fully anonymous and consisted exclusively of data collection and analysis, we consider ethical aspect of the study unquestionable.

\section{REFERENCES}

1. Gluvajić $D$, Bilban $M$, Hočevar Boltežar I. Ali je glasovna motnja lahko tudi poklicna bolezen? Zdrav Vestn. 2012;81:796-805.

2. Vilkman E. Voice problems at work: a challenge for occupational safety and health arrangement. Folia Phoniatr Logop. 2000;52:120-5.

3. Koufman JA, Isaacson G. The spectrum of vocal dysfunction. Otolaryngol Clin North Am. 1991;24:985-8.

4. Hah JH, Sim S, An SY, Sung MW, Choi HG. Evaluation of the prevalence of and factors associated with laryngeal diseases among the general population. Laryngoscope. 2015;125:2536-42. doi: 10.1002/ lary. 25424.

5. Jensen JB, Rasmussen N. Phonosurgery of vocal fold polyps, cysts and nodules is beneficial. Dan Med J. 2013;60:A4577.

6. Ju YH, Jung KY, Kwon SY, Woo JS, Cho JG, Park MW, et al. Effect of voice therapy after phonomicrosurgery for vocal polyps: a prospective, historically controlled, clinical study. J Laryngol Otol. 2013;127:1134-8. doi: 10.1017/S0022215113002454.

7. Titze IR, Lemke JH, Montequin D. Populations in the U.S. workforce who rely on voice as a primary tool of trade: a preliminary report. J Voice. 1997;11:254-9.

8. Roy N, Merrill RM, Gray SD, Smith EM. Voice disorders in the general population: prevalence, risk factors, and occupational impact. Laryngoscope. 2005;115:1988-95. doi: 10.1097/01. mlg.0000179174.32345.41.

9. Cohen SM, Kim J, Roy N, Asche C, Courey M. The impact of laryngeal disorders on work-related dysfunction. Laryngoscope. 2012;122:1589-94. doi: 10.1002/lary.23197.

10. Boltežar L, Šereg-Bahar M. Voice disorders in occupations with vocal load in Slovenia. Zdr Varst. 2014;53:304-10. doi: 10.2478/sjph-20140033.

11. Trinite B. Epidemiology of voice disorders in Latvian school teachers. J Voice. 2017;31:508.e1-9. doi: 10.1016/j.jvoice.2016.10.014.

12. Mozzanica F, Ginocchio D, Barillari R, Barozzi S, Maruzzi P, Ottaviani $\mathrm{F}$, et al. Prevalence and voice characteristics of laryngeal pathology in an Italian voice therapy-seeking population. J Voice. 2016;30:774. e13-21. doi: 10.1016/j.jvoice.2015.11.018.
13. Hegde MC, Kamath MP, Bhojwani K, Peter R, Babu PR. Benign lesions of larynx - a clinical study. Indian J Otolaryngol Head Neck Surg. 2005;57:35-8. doi: 10.1007/BF02907624.

14. de Medeiros AM, Assunção AÁ, Barreto SM. Absenteeism due to voice disorders in female teachers: a public health problem. Int Arch Occup Environ Health. 2012;85:853-64. doi: 10.1007/s00420-011-0729-1.

15. Kravos A. Voice disorders in sellers. Med Razgl. 2008;47:383-6.

16. Žirovec P. Glasovne motnje pri medicinskih sestrah: diplomska naloga. Ljubljana: Pedagoška fakulteta, 2014.

17. Hočevar Boltežar I. Prevalence and risk factors for voice problems in priests. Wien Klin Wochenschr. 2009;121:276-81. doi: 10.1007/ s00508-009-1163-1.

18. Cohen SM, Kim J, Roy N, Courey M. Delayed otolaryngology referral for voice disorders increases health care costs. Am J Med. 2015;128:426.e11-8. doi: 10.1016/j.amjmed.2014.10.040.

19. Pickhard A, Reiter R. Benign vocal fold lesions. Laryngorhinootologie. 2013;92:304-12. doi: 10.1055/s-0032-1331162.

20. Luyten A, Bruneel L, Meerschman I, D' haeseleer E, Behlau M, Coffé C, et al. Prevalence of vocal tract discomfort in the Flemish population without self-perceived voice disorders. J Voice. 2016;30:308-14. doi: 10.1016/j.jvoice.2015.04.017.

21. Soklič T, Hočevar Boltežar I. Glasovne motnje med pedagoškimi delavci v Sloveniji: prevalenca in nekateri dejavniki tveganja. Zdrav Vestn. 2004;73:493-7.

22. Ruotsalainen J, Sellman J, Lehto L, Verbeek J. Systematic review of the treatment of functional dysphonia and prevention of voice disorders. Otolaryngol Head Neck Surg. 2008;138:557-65. doi: 10.1016/j.otohns.2008.01.014

23. Vilkman E. Occupational safety and health aspects of voice and speech professions. Folia Phoniatr Logop. 2004;56:220-53.

24. Duffy $O M$, Hazlett $D E$. The impact of preventive voice care programs for training teachers: a longitudinal study. J Voice. 2004;18:63-70.

25. Sapir S, Keidar A, Mathers-Schmidt B. Vocal attrition in teachers: survey findings. Eur J Disord Commun. 1993;28:177-85.

26. O'Neill J, McMenamin R. Voice use in professional soccer management. Logoped Phoniatr Vocol. 2014;39:169-78. doi: 10.3109/14015439.2013.825008.

27. Sala E, Airo E, Olkinuora P, Simberg S, Strom U, Laine A, et al. Vocal loading among day care center teachers. Logoped Phoniatr Vocol. 2002;27:21-8.

28. Holmberg EB, Doyle P, Perkell JS, Hammarberg B, Hillman RE. Aerodynamic and acoustic voice measurements of patients with vocal nodules: variations in baseline and changes across voice therapy. J Voice. 2003;17:269-82. doi: 10.1067/S0892-1997(03)00076-6

29. Lowenthal $\mathrm{G}$. The treatment of polypoid laryngitis. Laryngoscope. 1958:1095-104.

30. Snow JB. Surgical therapy for vocal dysfunction. Otolaryngol Clin North Am. 1984;17:91-100.

31. Nielsen VM, Hojslet PE, Karlsmose M. Surgical treatment of Reinke's edema. J Laryngol Otol. 1986;100:187-90.

32. Cohen SM, Kim J, Roy N, Courey M. Prescribing patterns of primary care physicians and otolaryngologist in the management of laryngeal disorders. Otolaryngol Head Neck Surg. 2013;149:118-25. doi: 10.1177/0194599813485360.

33. Cohen SM, Kim J, Roy N, Courey M. Factors influencing referral of patients with voice disorders from primary care to otolaryngology. Laryngoscope. 2014;124:214-20. doi: 10.1002/lary.24280. 